\title{
KAJIAN STANDAR STRUKTUR BIAYA
}

\section{AA Nova Swandana}

Email: amertajati@gmail.com

\section{Intisari}

Standar Struktur Biaya merupakan langkah awal dalam mendukung efisiensi alokasi biaya dalam penyusunan RKA-KL dan menghasilkan pengaturan standar struktur biaya sesuai amanat pasal 26 PMK Nomor 71/PMK.02/2012. Standar struktur biaya sebagaimana dimaksud pada PMK tersebut adalah batasan komposisi biaya tertentu atas suatu keluaran (output)/kegiatan/program tertentu yang ditetapkan oleh Menteri Keuangan selaku pengelola fiskal (chief financial officer) sebagai acuan dalam penyusunan RKA-K/L. Menteri Keuangan telah mengarahkan kepada para pengelola keuangan untuk melakukan efisiensi anggaran biaya pendukung seperti biaya perjalanan dinas dan rapat-rapat di luar kantor. Hal ini menjadi konsen bersama dalam upaya peningkatan kualitas penganggaran, berupa pengetatan efisiensi dalam pelaksanaan pelayanan pemerintah melalui pembatasan biayabiaya tertentu seperti biaya pendukung dan biaya perjalanan dinas yang tidak secara langsung menunjang pencapaian suatu keluaran/output kegiatan. Dengan menggunakan metode statistik dan software pengolah data SPSS, analisa kajian menggunakan confidential interval terhadap data tahun 2014 untuk seluruh K/L menunjukkan untuk besaran biaya pendukung output jasa layanan non-regulasi disarankan sebesar $45 \%$ dari total biaya output. Hal ini pada hakekatnya bersifat konservatif mengingat hal ini merupakan pengaturan yang baru dan akan dievaluasi besarannya setiap tahun. Oleh karena itu yang diatur baru pada output jasa layanan non regulasi sebelum jenis output/kegiatan yang lain.

Kata kunci: standar struktur biaya, standar biaya, efisiensi

\section{PENDAHULUAN}

\subsection{Latar Belakang}

$$
\text { Dalam rangka mewujudkan }
$$
anggaran yang efektif dan efisien, terdapat tiga pendekatan sistem penganggaran, yaitu kerangka pengeluaran jangka menengah (medium term expenditure framework), penganggaran terpadu (unified budget) dan penganggaran berbasis kinerja (performance based budgetting). Konsepsi performance based budgetting sendiri menekankan bahwa alokasi anggaran harus dioptimalkan untuk menghasilkan outcome yang ditujukan bagi pemenuhan kebutuhan masyarakat (people need). Namun demikian, harapan atas capaian terhadap outcome terkadang tidak menjadi tujuan dengan ditandai oleh banyaknya biaya-biaya pendukung (administratif) yang tidak terlalu diperlukan. Oleh karena itu, dalam rangka memperbaiki dan meningkatkan kualitas penganggaran, perlu pengaturan pembatasan biaya-biaya tertentu seperti biaya pendukung dan biaya perjalanan dinas yang tidak secara langsung menunjang pencapaian suatu keluaran/output kegiatan.

Sejalan dengan itu, dalam berbagai kesempatan baik Presiden maupun Menteri Keuangan telah memberikan arahan kepada para pengelola keuangan untuk melakukan efisiensi anggaran biaya 
pendukung seperti biaya perjalanan dinas dan rapat-rapat di luar kantor. Hal ini menjadi konsen bersama dalam upaya peningkatan kualitas penganggaran, yakni memperketat efisiensi dalam pelaksanaan pelayanan pemerintah.

Berkenaan hal tersebut di atas, sebagai penunjangdalam upaya meningkatkan kualitas penganggaran khususnya tentang efisiensi maka perlu pengaturan perubahan unsur-unsur biaya tertentu yang tidak memberikan nilai tambha pada peningkatan pelayanan pemerintah. Hal ini juga menjadi langkah penyeimbang atas prinsip "let the manager manage" agar pengeluaran negara lebih dapat terkontrol dan fokus pada hal yang memang menjadi kebutuhan.

Guna mendukung checks and balancespada proses perencanaan dan penganggaran pada internal kementerian negara/lembaga khususnya bagi Setjen K/L sebagai koordinator perencanaan dan penganggaran dan Itjen $\mathrm{K} / \mathrm{L}$ sebagai reviewer $R K A-K / L$, diperlukan instrumen untuk meningkatkan kualitas perencanaan dan penganggaran dan mendorong penganggaran yang lebih efisien.Berkenaan dengan hal tersebut, pasal 26 PMK No. 71/PMK.02/2013 tentang Pedoman Standar Biaya, Standar Struktur Biaya dan Indeksasi dalam Penyusunan RKA-K/L mengamanatkan bahwa dalam rangka mendukung efisiensi alokasi biaya, Menteri Keuangan menetapkan standar struktur biaya.

\subsection{Identifikasi Masalah}

Sebagaimana disebutkan dalam pendahuluan bahwa kondisi saat ini perlu memperhatikan value for money atas apa yang dibiayai oleh negara.dari berbagai masukan yang ada, disimpulkan bahwa prinsip let the manager manage memiliki ekses dari sisi efisiensi, salah satu contohnya adalah pelaksanaan kegiatan dengan biaya yang besar. Namun demikian, mengingat besar atau kecil merupakan suatu ukuran relatif jika tidak ada pembanding, maka perlu suatu alat sebagai pembanding.

Kajian ini berupaya memberikan perbandingan atas biaya tertentu dalam RKA-K/L dengan melakukan pembandingan, maka akan dapat diketahui kecenderungan atas biaya suatu kegiatan/keluaran termasuk komponennya. Pendekatan yang digunakan dalam kajian ini adalah membandingkan biaya pendukung terhadap total biaya.

\subsection{Tujuan}

Untuk menghasilkan pengaturan standar struktur biaya sesuai amanat pasal 26 PMK Nomor 71/PMK.02/2012 yang mengamanatkan penyusunan standar struktur biaya yang ditetapkan oleh Menteri Keuangan dalam rangka mendukung efisiensi alokasi biaya dalam penyusunan RKA-KL.

\section{METODOLOGI PENELITIAN}

Kajian ini dibuat dengan menggunakan metode statistik confidential interval menggunakan software pengolah data SPSS.

\subsection{Sumber Data}

Data yang digunakan merupakan data sekunder, yaitu data yang diperoleh dari Bussines Intelligence (BI). Data $\mathrm{BI}$ 
adalah database yang diperoleh dari RKA$\mathrm{K} / \mathrm{L}$ seluruh $\mathrm{K} / \mathrm{L}$. Dari $\mathrm{BI}$ diperoleh data alokasi anggaran yang dirinci berdasarkan organisasi, fungsi, dan jenis belanja. Data dimaksud yaitu data RKA-K/L khususnya terkait dengan penerapan biaya pendukung dan biaya perjalanan dinas pada 17.000 output yang terbagi dalam 4 kategori yaitu output barang infrastruktur, barang non infrastruktur, jasa regulasi, dan jasa layanan non-regulasi.

\subsection{Pengolahan Data}

Metode yang kami gunakan dalam mengolah data tersebut adalah sebagai berikut:

a. Membagi output kedalam 4 (empat) kategori meliputi barang infrastruktur, barang non infrastruktur, jasa regulasi, dan jasa layanan non-regulasi. Klasifikasi ini dibuat berdasarkan profesional adjusment pimpinan $\mathrm{Hal}$ ini dimaksudkan untuk memperjelas apa yang akan dilakukan sesuai karakteristik masing-masing data yang berbeda tujuannya.

b. Menentukan komponen utama dan komponen pendukung dari tiap output tersebut serta memilah komponen tersebut sampai dengan jenis belanjanya. Dengan demikian pdat dilihat komponen mana saja yang mendukung secara langsung dan tidak langsung dalam pencapaian output.

c. Membandingkan antara jenis komponen dengan mempertimbangkan jenis belanja untuk menghasilkan nilai persentase perbandingan.

d. Melakukan penghitungan untuk mendapatkan angka rata-rata serta menggunakan metode confidential interval untuk melihat kisaran angka yang akan dijadikan landasan benchmarking. Angka rata-rata ini adalah sebagai justifikasi yang akan digunakan dalam benchmarking antar $\mathrm{K} / \mathrm{L}$ dan dapat digunakan sebagai estimasi jumlah ideal yang dibutuhkan dalam pencapaian output.

\section{TINJAUAN PUSTAKA}

\subsection{Terminologi dan Dasar Hukum}

Standar Struktur Biaya (SSB) adalah batasan komposisi biaya atas suatu keluaran (output)/kegiatan/program tertentu yang ditetapkan oleh Mneteri Keuangan selkau pengelola fiskal (Chief Financial Officer). SSB ini berfungsi sebagai acuan bagi kementerian negara/lembaga dalam menyusun komposisi biaya tertentu dari suatu keluaran (output)/kegiatan/program tertentu dalam penyusunan rencana kerja dan anggaran kementerian negara/lembaga dan pelaksanaan anggaran. Indeksasi merupakan alat yang digunakan untuk penghitungan kebutuhan anggaran dalam kerangka pengeluaran jangka menengah. Indeksasi sendiri berfungsi sebagai penghitungan pagu kebutuhan alokasi biaya suatu keluaran (output) pada tahun anggaran yang direncanakan bagi dasar keluaran. Selain itu fungsi indeksasi sebagai penghitungan prakiraan maju tahun anggaran berikutnya bagi dasar keluaran (output baseline) dan inisiatif baru.

Dasar hukum yang melandasi perlunya standar struktur biaya dan indeksasi, yaitu:

1. UU No. 17 Tahun 2003 tentang Keuangan Negara Pasal 3 (1) bahwa 
“Keuangan Negara dikelola secara tertib, taat pada peraturan perundangundangan, efisien, ekonomis, efektif, transparan, dan bertanggung jawab dengan memperhatikan rasa keadilan dan kepatutan."

2. Amanat PMK No. 71/PMK.02/2013 Pasal 26 bahwa "dalam rangka mendukung efisiensi alokasi biaya dalam penyusunan RKA-K/L, Menteri Keuangan menetapkan Standar Struktur Biaya dan Indeksasi."

Tujuan utama dari pengaturan dimaksud adalah untuk meminimalisasi biaya birokrasi dalam menghasilkan pelayanan kepada masyarakat.

Pada tahap awal, penerapan SSB dilakukan pada level keluaran (output). Penetapan besaran SSB merujuk pada jenis keluaran (output) dalam RKA-K/L yang dikelompokkan sebagai berikut:

1. Keluaran (output) Barang, yang terdiri dari:

a. Output barang infrastruktur, yaitu output kegiatan yang merupakan barang berwujud dan atau berupa jaringan yang diperlukan untuk jaminan ekonomi sektor publik agar perekonomian dapat berfungsi dengan baik. Contoh: jalan, kereta api, air bersih, bandara, kanal, waduk, pengolahan limbah, dan sebagainya.

b. Output barang non infrastruktur, yaitu output kegiatan yang merupakan barang baik berwujud maupun tidak berwujud yang tidak berupa jaringan yang bukan termasuk barang infrastruktur. Contoh: kendaraan, software aplikasi, dan sebagainya.
2. Keluaran (output) Jasa, yang terdiri dari:

a. Output jasa regulasi/birokrasi, yaitu output yang dihasilkan dari suatu kegiatan dalam rangka pembuatan peraturan atau pendukung administrasi birokrasi. Bentuk output tersebut dapat berupa norma, standar, dan lain-lain.

b. Output jasa layanan, yaitu output dari suatu kegiatan yang merupakan layanan dari suatu instansi pemerintah. Contoh: SP2D, layanan BOS, dan sebagainya.

\subsection{Penerapan Standar Struktur Biaya TA 2016}

Penerapan standar struktur biaya idealnya dilakukan pada ke-empat jenis output dimaksud sehingga pembatasan biaya dapat berlaku pada semua output. Namun mengingat jenis output belum terdokumentasi dengan baik dalam RKA$\mathrm{K} / \mathrm{L}$ maka akan lebih tepat apabila penerapan dilakukan secara bertahap.Untuk tahap awal, penerapan Standar Struktur Biaya TA 2016 perlu dilakukan dengan pemilihan atas jenis output yang ada. Secara umum, output barang infrastruktur dan output jasa layanan lebih mudah untuk didentifikasi dibandingkan dengan output barang non infrastruktur dan output jasa regulasi. Kemudahan identifikasi sangatlah krusial mengingat analisis pengelompokkan jenis output dilakukan melalui judgement yang kemungkinan berbeda dengan penafsiran kementerian/lembaga. Namun demikian, karena output barang, baik untuk infrastruktur dan non-infrastruktur, sudah dilakukan upaya efisiensi melalui proses pengadaan secara kontraktual maka 
penerapan Standar Struktur Biaya TA 2016 akan diterapkan pada output jasa layanan khususnya layanan non regulasi.

Pengaturan Standar Struktur Biaya tidak diterapkan pada output/sub output yang ditetapkan dalam Peraturan Menteri Keuangan tentang Standar Biaya Keluaran (SBK) Tahun Anggaran 2016 mengingat :

1. Proses penetapan Standar Biaya Keluaran dalam Peraturan Menteri Keuangan tentang SBK Tahun Anggaran 2016 sedang berjalan, dimana rincian atas SBK tersebut telah ditelaah pada kesempatan pertama.

2. Hal ini dapat memberikan insentif bagi $\mathrm{K} / \mathrm{L}$ dalam menyusun SBK sehingga aspek strategis SBK sebagai alat efisiensi dapat berjalan dengan baik. Pemberian insentif tersebut akan dievaluasi sejalan dengan meningkatnya animo $\mathrm{K} / \mathrm{L}$ dalam menyusun SBK dimasa yang akan datang.

\subsection{Cakupan Pembatasan Biaya}

Output jasa layanan non-regulasi didefinisikan sebagai output dari suatu kegiatan yang merupakan wujud dari suatu layanan dari suatu instansi pemerintah. Contoh dari output jasa layanan adalah SP2D, layanan BOS, dan sebagainya.Berdasarkan hasil rapat pembahasan terakhir disepakati pengaturan standar struktur biaya untuk tahun anggaran 2016 dilakukan dengan melakukan pembatasan biaya pendukung yang diizinkan dari total biaya keluaran. Sementara pembatasan biaya perjalanan dinas, untuk saat ini belum dilakukan mengingat pembatasan biaya perjalanan dinas akan lebih efektif bila dilakukan dengan melakukan kebijakan penetapan satuan biaya perjalanan dinas yang tidak menimbulkan conflict of interest bagi pejabat/pegawai untuk mendapatkan tambahan penghasilan dari pelaksanaan perjalanan dinas.

Hal ini senada dengan dengan pembatasan honorarium, yang dilakukan melalui kebijakan pengendalian terhadap honorarium pada PMK Nomor 71/PMK.02/2013 juncto PMK 51/PMK.02/2014 dan penerapan remuneration system pada K/L. Adapun definisi biaya utama dan biaya pendukung adalah sebagai berikut:

1. Biaya Utama adalah semua biaya yang terkait langsung dengan pelaksanaan suatu kebijakan yang kebutuhannya dipengaruhi oleh total volume output yang akan dicapai.

2. Biaya Pendukung adalah semua biaya yang digunakan dalam rangka menjalankan dan mengelola suatu kebijakan yang kebutuhannya tidak terkait langsung dengan total volume output yang akan dicapai.

Pada kajian ini, pokok bahasannya akan direpresentasikan dalam skema yang tampak pada gambar berikut ini: 


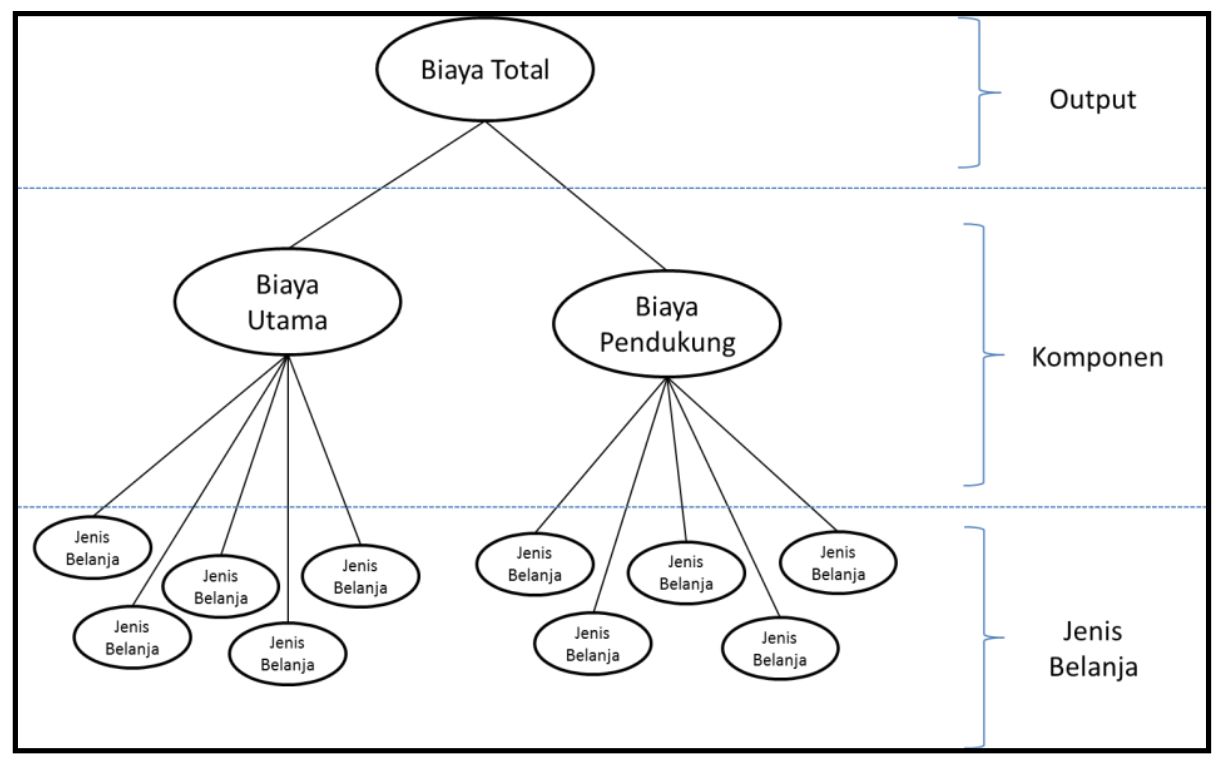

Gambar 1. Skema Biaya dalam RKA-K/L

Berdasarkan Gambar 1 tersebut, dapat disampaikan hal sebagai berikut:

Biaya total dari suatu output terdiri dari komponen utama dan komponen pendukung.

Biaya utama dan biaya pendukung sendiri terdiri dari bermacam-macam jenis belanja, (namun jenis belanja yang dibahas dalam kajian ini adalah jenis biaya perjalanan dinas).

Persentase merupakan inti dari kajian ini. Terdapat tiga hal yang menjadi fokus dalam mencari persentase ini, yaitu:

1. Persentase biaya pendukung atas biaya total

merupakan jumlah biaya pendukung dibagi dengan biaya total dikalikan seratus persen.

2. Persentase biaya perjalanan dinas atas biaya total

merupakan jumlah biaya perjalanan dinas baik dalam biaya utama maupun biaya pendukung dibagi dengan biaya total dikalikan seratus persen.

3. Persentase biaya perjalanan dinas pendukung atas biaya total adalah jumlah biaya perjalanan dinas untuk kategori biaya pendukung dibagi dengan biaya total dikalikan seratus persen.

Ilustrasi dari nomor $1-3$ adalah sebagai berikut :

1.

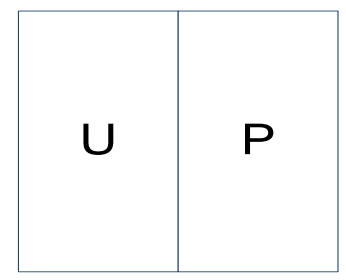

Cara menghitung Persentase biaya pendukung atas biaya total adalah sebagai berikut:

$\% \mathrm{PT}=\mathrm{P} / \mathrm{T} \times 100 \%$

$\% \mathrm{PT}=$ Persentase biaya pendukung atas biaya total

$\mathrm{P}=$ biaya pendukung

$\mathrm{T}=$ biaya total

2.

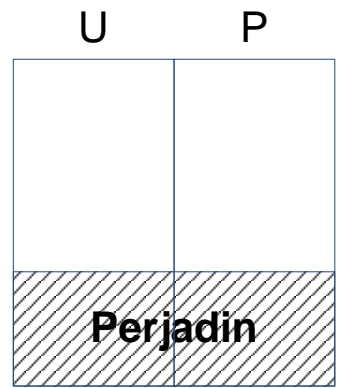


Cara menghitung Persentase biaya perjalanan dinas atas biaya total adalah sebagai berikut:

\section{$\% \mathrm{PjT}=\mathrm{Pj} / \mathrm{T} \times 100 \%$}

$\% \mathrm{PjT}=$ Persentase biaya perjalanan dinas atas biaya total

$\mathrm{Pj}=$ biaya Perjalanan dinas

$\mathrm{T}=$ biaya total

3.

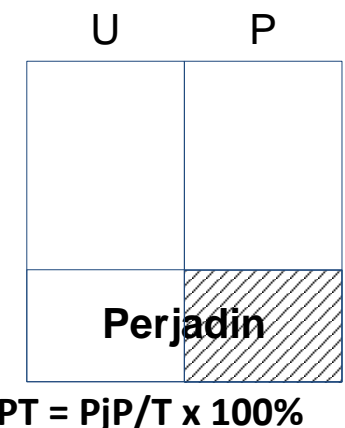

\% PjPT = Persentase biaya perjalanan dinas pendukung atas biaya total
$\mathrm{Pj} \quad=$ biaya Perjalanan dinas pendukung

$\mathrm{T} \quad=$ biaya total

\section{PEMBAHASAN}

\subsection{Hasil Pengolahan Data}

Data RKA-K/L TA 2014 dikaji dengan menilai tingkat kewajaran biaya pendukung atas biaya keluaran dan komposisi biaya perjalanan dinas atas biaya keluaran. Data yang telah diperoleh diolah dengan software statistik SPSS menggunakan metode confidential interval dan menghitung rata-ratanya.Dari hasil pengolahan tersebut diperoleh hasil sebagai berikut:

1. Kelompok Kode 2 (Barang Non Infrastruktur)

Tabel 1 Hasil Pengolahan Data untuk Barang Non Infrastruktur

\begin{tabular}{|l|l|l|l|}
\hline & $\begin{array}{c}\text { Metode Confidential } \\
\text { Interval }\end{array}$ & $\begin{array}{c}\text { Metode } \\
\text { Rata-rata }\end{array}$ & \multicolumn{1}{|c|}{ Standar Deviasi } \\
\hline BiayaPendukung/BiayaTotal & $16,42 \%-37,40 \%$ & $35,96 \%$ & 0,307443006 \\
\hline BiayaPerjadin/BiayaTotal & $67,73 \%-88,88 \%$ & $66,30 \%$ & 0,309963938 \\
\hline BiayaPerjadinPendukung/BiayaTotal & $0 \%-15,69 \%$ & $12,22 \%$ & 0,250310575 \\
\hline
\end{tabular}

Pada Tabel 1 tersebut diketahui bahwa rata-rata untuk biaya pendukung atas biaya total $35,96 \%$. Persentase tersebut berada dalam batas toleransi kewajaran penggunaan anggaran. Berdasarkan metode confidential interval batas toleransi kewajaran penggunaan anggaran yaitu $16,42 \%$ sampai $37,40 \%$. Sedangkan rata-rata untuk biaya perjalanan dinas atas biaya total persentasenya $66,30 \%$ dan angka tersebut berada dalam batas toleransi kewajaran yaitu $67,73 \%$ sampai $88,88 \%$.

Persentase biaya perjalanan dinas untuk biaya pendukung atas biaya total sebesar 12,22\%. Rata-rata tersebut berada dalam batas toleransi kewajaran penggunaan anggaran yaitu 0\%-15,69\%. 
2. Kelompok Kode 3 (Jasa Regulasi)

Tabel 2 Hasil Pengolahan Data untuk Jasa Regulasi

\begin{tabular}{|l|c|c|c|}
\hline & $\begin{array}{c}\text { Metode Confidential } \\
\text { Interval }\end{array}$ & $\begin{array}{c}\text { Metode } \\
\text { Rata-rata }\end{array}$ & $\begin{array}{c}\text { Standar } \\
\text { Deviasi }\end{array}$ \\
\hline BiayaPendukung/BiayaTotal & $56,47 \%-57,73 \%$ & $57,10 \%$ & 0,27833 \\
\hline BiayaPerjadin/BiayaTotal & $49,27 \%-50,59 \%$ & $49,93 \%$ & 0,28876 \\
\hline BiayaPerjadinPendukung/BiayaTotal & $37,98 \%-39,46 \%$ & $38,72 \%$ & 0,326522 \\
\hline
\end{tabular}

Pada Tabel 2 tersebut diketahui bahwa rata-rata untuk biaya pendukung atas biaya total $57,10 \%$. Persentase tersebut berada dalam batas toleransi kewajaran penggunaan anggaran. Berdasarkan metode confidential interval batas toleransi kewajaran penggunaan anggaran yaitu $56,47 \%-57,73 \%$. Sedangkan ratarata untuk biaya perjalanan dinas atas biaya total persentasenya $49,93 \%$ dan

3. Kelompok Kode 4 (Jasa Layanan) angka tersebut berada dalam batas toleransi kewajaran yaitu 49,27\%-50,59\%. Persentase biaya perjalanan dinas untuk biaya pendukung atas biaya total sebesar $38,72 \%$. Ratarata tersebut berada dalam batas toleransi kewajaran penggunaan anggaran yaitu $37,98 \%-39,46 \%$.

Tabel 3 Hasil Pengolahan Data untuk Jasa Layanan

\begin{tabular}{|l|c|c|c|}
\hline & $\begin{array}{c}\text { Metode Confidential } \\
\text { Interval }\end{array}$ & $\begin{array}{c}\text { Metode } \\
\text { Rata-rata }\end{array}$ & $\begin{array}{c}\text { Standar } \\
\text { Deviasi }\end{array}$ \\
\hline BiayaPendukung/BiayaTotal & $46,27 \%-47,87 \%$ & $47,07 \%$ & 0,289645 \\
\hline BiayaPerjadin/BiayaTotal & $47,02 \%-48,61 \%$ & $47,82 \%$ & 0,287489 \\
\hline BiayaPerjadinPendukung/BiayaTotal & $37,27 \%-38,96 \%$ & $38,12 \%$ & 0,306113 \\
\hline
\end{tabular}

Pada Tabel 3 tersebut diketahui bahwa rata-rata untuk biaya pendukung atas biaya total $47,07 \%$. Persentase tersebut berada dalam batas toleransi kewajaran penggunaan anggaran. Berdasarkan metode confidential interval batas toleransi kewajaran penggunaan anggaran yaitu $46,27 \%-47,87 \%$. Sedangkan ratarata untuk biaya perjalanan dinas atas biaya total persentasenya $47,82 \%$ dan angka tersebut berada dalam batas toleransi kewajaran yaitu $47,02 \%-48,61 \%$. Persentase biaya perjalanan dinas untuk biaya pendukung atas biaya total sebesar $38,12 \%$. Rata-rata tersebut berada dalam batas toleransi kewajaran penggunaan anggaran yaitu $37,27 \%-38,96 \%$. 


\section{PENUTUP}

\subsection{Kesimpulan}

Berdasarkan analisis yang dilakukan terhadap data RKA-K/L atas output jasa layanan dengan menggunakan metode statistik confidential interval diperoleh besaran biaya-biaya administrasi keluaran (output) yang realistis dari total biaya output adalah 45\%. Pemilihan besaran $45 \%$ merupakan upaya untuk menekan biaya pendukung yang selama ini dirasa terlalu besar. Bentuk pengaturan penerapan standar struktur biaya adalah sebagai berikut:

\begin{tabular}{|l|l|c|}
\hline $\begin{array}{c}\text { JENIS } \\
\text { KELUARA } \\
\text { N/(OUTP } \\
\text { UT) }\end{array}$ & PENGATURAN & $\begin{array}{c}\text { BESARA } \\
\text { N }\end{array}$ \\
\hline $\begin{array}{l}\text { Jasa } \\
\text { Layanan } \\
\text { non- } \\
\text { regulasi }\end{array}$ & $\begin{array}{l}\text { Besaran biaya } \\
\text { pendukung } \\
\text { tertinggi yang } \\
\text { diizinkan dari } \\
\text { total biaya } \\
\text { keluaran } \\
\text { (output) }\end{array}$ & $45 \%$ \\
\hline
\end{tabular}

Penerapan kebijakan batasan besaran biaya pendukung untuk output jasa layanan non regulasi pada RKA-K/L sebesar $45 \%$ pada hakekatnya bersifat konservatif (dalam batas aman untuk dilaksanakan, tidak terlalu tinggi ataupun terlalu rendah, sehingga dapat diterapkan /kegiatan dapat dilaksanakan dengan menghindari kemungkinan kegiatan under budget/over budget), mengingat hal ini merupakan pengaturan yang baru dan akan dievaluasi besarannya setiap tahun.

\subsection{Rekomendasi}

1. Dari keempat jenis output dimaksud, kami berpendapat :

a. barang infrastruktur, tidak perlu dijadikan objek penerapan SSB karena sudah ada pengaturan prosentase biaya pembangunan atas bangunan/konstruksi negara dari Kementerian PU.

b. barang non infrastruktur, belum perlu menjadi prioritas objek penerapan SSB

c. jasa regulasi, belum perlu menjadi prioritas objek penerapan SSB karena

d. jasa layanan non-regulasi perlu dijadikan sebagai objek penerapan standar struktur biaya TA 2016 untuk memastikan biaya administrasi/pendukung birokrasi yang digunakan dalam mendukung atau mengelola suatu output lebih efisien sehingga sebagian besar alokasi yang diberikan digunakan hal-hal yang berkaitan langsung dengan output yang dihasilkan

2. Berdasarkan kajian, maka kami rekomendasikan penerapan standar struktur biaya TA 2016 akan difokuskan pada pembatasan biaya pendukung dan/atau biaya perjalanan dinas pada pembiayaan output jasa regulasi dan jasa layanan non-regulasi. 